\title{
A Role of Cell Adhesion Molecules and Gelatinases in Human Serum-Induced Aggregation of Human Eyelid-Derived Stem Cells In Vitro
}

\author{
Hyejin Yang, Yoon Hwa Lim, Sujin Yun, A Young Yoon and ${ }^{\dagger}$ Haekwon Kim \\ Department of Biotechnology, Seoul Women's University, Seoul 139-774, Republic of Korea
}

\begin{abstract}
Human serum (HS) has been reported to induce aggregation of human eyelid adipose-derived stem cells (HEACs) during high-density culture in vitro. The present study focused on the role of cell adhesion molecules and gelatinases during HS-induced aggregation of HEACs. HS-induced aggregation occurred between 9-15 days of culture. Cells aggregated by HS medium (HS-agg) showed stronger expression of $\alpha 2, \alpha 2 B, \alpha X$, and CEACAM1 genes compared to non-aggregated cells in HS medium (HS-ex) or in control FBS-cultured cells. HS-agg were distinctly labeled with antibodies against $\alpha 2, \alpha 2 \mathrm{~B}$, and $\alpha \mathrm{X}$ proteins. Western blot results demonstrated that the two integrin proteins were greatly expressed in HS-agg compared to HS-ex and control FBS-cultured cells. Treatment of HEACs with anti-integrin $\alpha 2$ antibody during culture in HS medium delayed aggregation formation. HS-agg exhibited strong expression of MMP1 and MMP9 compared to HS-ex or FBS-cultured cells. Conditioned media from HS-culture showed remarkable increase of MMP9 gelatinolytic activity in comparison to those from FBS-culture. However, there was no change of TIMP mRNA expression in relation to the HS-induced aggregation. Based on these results, it is suggested that integrin $\alpha 2, \alpha 2 \mathrm{~B}$, and $\alpha \mathrm{X}$, and MMP9 might play an important role in the HS-induced aggregation of HEACs.
\end{abstract}

Key words : Aggregation, Human eyelid adipose-derived stem cells, Human serum, Integrin, MMP

\section{INTRODUCTION}

Mesenchymal stem cells (MSCs) are a heterogeneous cell population characterized by plastic adherence, selfrenewal capabilities, and multi-differentiation potential into osteoblasts, adipocytes, chondrocytes, and other cells. They are considered as good candidates for therapeutic cells due to limited tendency to produce tumors and immunologically privileged nature (Uccelli et al., 2008). It has been shown that MSCs migrate to injured tissues, then differentiate into tissue-specific cells or promote regeneration by secretion of bioactive factors. Their therapeutic effects have been demonstrated in various disease models such as heart, brain, liver, spleen, and lungs (Bianco et al., 2008). Bone marrow-derived stem cells (BM-MSCs) are the most well-known and characterized MSCs, but their invasive procedure lead to a limited availability for clinical application. Multipotent stem cells present in adipose tissue, adipose-derived stem cells (ADSCs), are promising stem cell population, since human adipose tissue is ubiquitous and easily obtained in large quantities with little donor site morbidity or patient discomfort. The use of autologous ADSCs as both research tools and as cellular therapeutics is feasible and has been shown to be both safe and efficacious in preclinical and clinical studies of injury and disease (Mizuno et al., 2012).

Intravenous infusion of MSCs is the most practical route of administration for many therapeutic objectives.

\footnotetext{
Manuscript received 26 November 2013, Received in revised form 15 December 2013, Accepted 20 December 2013

${ }^{\dagger}$ Corresponding Author : Haekwon Kim, Department of Biotechnology, Seoul Women’s University, Seoul 139-774, Republic of Korea. Tel. : +82-2-970-5665, Fax : +82-2-974-2473, E-mail : hwkim@swu.ac.kr

This is an Open Access article distributed under the terms of the Creative Commons Attribution Non-Commercial License(http://creativecommons. org/licenses/by-nc/3.0) which permits unrestricted non-commercial use, distribution, and reproduction in any medium, provided the original work is properly cited.
} 
It is well known that engrafted cells home to injured tissue by various signals such as chemokines, integrins and matrix metalloproteinases (MMPs) (Sarkar et al., 2011). For example, MSC migration at the fracture site is well known to be time- and dose-dependent and is exclusively CXCR4-dependent (Granero-Moltó et al., 2009). Integrins are heterodimeric transmembrane protein receptors consisting of noncovalently linked $\alpha$ and $\beta$ subunits (Prowse et al., 2011). They affect many processes, including cell-cell adhesion, cell-ECM adhesion, cellular differentiation, proliferation, motility, and signal transduction. Human BM-MSCs are known to express a broad range of integrins in their undifferentiated state such as $\alpha 1-6,10,11, \mathrm{~V}$ and $\beta 1-8$ (Brooke et al., 2008). They show a dramatic, though transient, increase in the level of $\alpha 5$ integrin on day 7 of osteogenesis and an increase in a6 integrin expression throughout adipogenesis, and presentation of RGD peptides, which is bound by multiple integrins, was shown to be required to support long-term viability of hMSCs (Frith et al., 2012). Knockdown of the a6 integrin subunit in BM-MSCs significantly reduces capillary sprouting, and causes their failure to associate with the nascent vessels (Carrion et al., 2013). Adhesion, homing, lodging and retention of haematopoietic stem cells and progenitors in the bone marrow have also been shown to occur through Rab5-dependent post-translational regulation of $\beta 1 / \beta 2$ integrins (Taniguchi Ishikawa et al., 2013). MMPs are proteolytic enzymes that depend on binding with a $\mathrm{Zn}^{2+}$ ion for their catalytic activity. Two groups of MMPs are known, soluble, and membrane anchored. Most of the soluble MMPs are secreted as inactive prozymogens and activated by other proteases through cleavage of their $\mathrm{N}$-terminal prodomains. The proteolytic activity of MMPs in the extracellular space is controlled by a series of natural endogenous inhibitors, with TIMPs representing the major group of proteins involved in this inhibition. Migration of BM-MSCs through bone marrow endothelium was shown to involve MMP-2, and the migration was decreased by TIMP-3 (De Becker et al., 2007). The inflammatory cytokines TGF-beta1, IL-1beta, and TNF-alpha up-regulate
MMP-2, MT1-MMP, and/or MMP-9 production in MSCs, resulting in a strong stimulation of chemotactic migration through ECM. (Ries et al., 2007). Collectively these studies demonstrate that migration of MSCs could be regulated by cytokines, MMPs and TIMPs.

Fetal bovine serum (FBS) used in cell expansion protocols provides vital nutrients, attachment factors, toxin scavengers and growth factors. However, it is unsuitable for therapeutic purposes due to the ill-defined nature, high lot-to-lot variable composition, the risk of transmitting infectious agents and immunizing effects. Various supplements have been developed to replace FBS such as a fully chemically defined medium and pooled human $\mathrm{AB}$ serum (Tateishi et al., 2008; Bieback et al., 2012). Human factors purified from serum or platelets have also been suggested as alternatives for clinical scale manufacturing (Bieback et al., 2010). Previously, we have observed that human eyelid adiposederived stem cells (HEACs) cultured in medium containing human serum (HS) readily formed aggregation and the aggregated cells followed by disaggregation in FBS medium maintained their stem cell characteristics (Song et al., 2012).

In this study, we aimed to investigate the expression of cell-adhesion molecules and MMPs in cell aggregates formed by high-density culture of HEACs in the presence of HS. We observed that the expression of integrin $\alpha 2$, $\alpha 2 \mathrm{~B}, \alpha \mathrm{X}, \mathrm{MMP} 1$ and MMP9 genes in HS-agg of HEACs, and MMP9 enzymatic activity remarkably increased during culture. These results suggest that integrins and MMPs might be involved in the HS-induced aggregation of HEACs.

\section{MATERIALS AND METHODS}

\section{Reagents}

Human serum (HS) was purchased from Millipore (Millipore, Temecula, CA). It was inactivated at $56^{\circ} \mathrm{C}$ for $30 \mathrm{~min}$ and aliquots were stored in $50-\mathrm{ml}$ tube at $-20 \mathrm{C}$ until use. All reagents were purchased from Sigma unless stated otherwise.

\section{Isolation and culture of HEACs}


A Role of Cell Adhesion Molecules and Gelatinases in Human Serum-Induced Aggregation of Human Eyelid-Derived Stem Cells

Human eyelid adipose tissues were obtained from ten

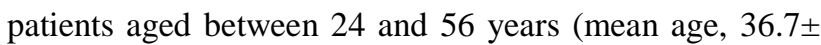
4.7 years) undergoing cosmetic surgery in local hospital in Seoul with informed consent. About $0.5 \mathrm{~g}$ of tissue specimen was usually obtained by an individual. All experiments were approved by Institutional Review Board of Seoul Women's University. Cells were prepared as described previously (Kang et al., 2009). Tissues were washed with Dulbecco's phosphate buffered saline (DPBS, Gibco, Grand Island, NY) containing Antibiotic-Antimycotic (Gibco) and treated with $1 \times$ volume of $0.15 \%$ type I collagenase (Gibco) in DPBS for $30 \mathrm{~min}$ at $37^{\circ} \mathrm{C}$ with gentle stirring. Then an equal volume of Dulbecco's modified Eagle's medium-low glucose type (5.5 mM; DMEM, Gibco) supplemented with Antibiotic-Antimycotic (Gibco), $3.7 \mathrm{mg} / \mathrm{ml}$ sodium bicarbonate and 10\% FBS (Gibco) was added to neutralize the enzymatic activity. After centrifugation at 3,000 rpm for $10 \mathrm{~min}$, the supernatant was removed and the remaining cell pellet was washed several times with DMEM. For the routine culture, cells were plated in $25-\mathrm{cm}^{2}$ culture flask (Nunc, Rockilde, Denmark) containing $5 \mathrm{ml}$ of DMEM supplemented with Antibiotic-Antimycotic, $3.7 \mathrm{mg} / \mathrm{ml}$ sodium bicarbonate, and $10 \%$ FBS. Cells were cultivated at $37^{\circ} \mathrm{C}$ with $5 \%$ CO2. The medium was changed twice a week. HEACs at passage 3 (p3) to p6 were used in this study.

\section{Aggregation assay}

HEACs were seeded in 6-well plate (Nunc, Shanghai, China) at a density of $2 \times 10^{5}$ cells/well. Cells were cultivated with $5 \mathrm{ml}$ of DMEM containing 10\% of either FBS or HS. Morphological change was observed every day during culture until 20 days. Around the time of aggregation, cells were treated with Hank's balanced salt solution containing $0.125 \%$ trypsin and $1 \mathrm{mM}$ EDTA for 2 min at $37^{\circ} \mathrm{C}$. Then DMEM containing $10 \%$ FBS was added to stop the enzymatic activity. After several washing, cell number was counted.

\section{Quantitative reverse transcription-polymerase chain}

reaction (qRT-PCR)

Total RNA was isolated using Tri-reagent (Ambion, Carlsbad, CA) according to the manufacturer's instructions. RT-PCR was performed using a Techne PCR system TC-100 (Bibby Scientific, UK). Total RNA was reversetranscribed using the following RT mixture: $20 \mathrm{mM} \mathrm{MgCl}_{2}$ (Bio Basic, Ontario, Canada), $10 \times$ PCR buffer (BioBasic), $10 \mathrm{mM}$ dNTPs mixture (BioBasic), $40 \mathrm{U} / \mu \mathrm{l}$ RNase inhibitor (BioBasic), $0.5 \mathrm{mg} / \mathrm{ml}$ random hexamer (Roche, New jersey, USA) and $200 \mathrm{U} / \mu \mathrm{l}$ AMV-RT (Invitrogen, Carlsbad, CA). Quantitative RT-PCR was performed using $150 \mathrm{ng} / \mathrm{ml}$ cDNA, primers, and $10 \mu \mathrm{l}$ SYBRGreen Master mix (Roche, Mannheim, Germany), and $10 \mathrm{pmol}$ of each primer using LightCycler 480 Real-Time System (Roche). Relative expression levels were normalized using 18s rRNA and the comparative CT $\left(2^{-\Delta} \mathrm{CT}\right)$ method. Primers used in the experiment are shown in supplementary Table 1.

\section{Cryosection}

Aggregations were collected with pipette tips, transferred into a 15-ml conical tube, washed twice with PBS, and fixed with $4 \%$ paraformaldehyde (Merck, Darmstadt, Germany) in PBS for overnight at $4{ }^{\circ} \mathrm{C}$ and incubated at $4{ }^{\circ} \mathrm{C}$ overnight in $200 \mu \mathrm{l}$ of $20 \%$ sucrose solution in PBS. After incubation, aggregations were embedded in frozen section compound OCT (Leica biosystems, Richmond, USA). The mold sample was frozen by liquid nitrogen and stored at $-80^{\circ} \mathrm{C}$. Specimens were frozen-sectioned with 5- $\mu \mathrm{m}$ size using Leica CM3050S cryostat (Leica Microsystems) and processed for immunohistochemistry.

\section{Immunocytochemistry}

Aggregations were collected with pipette tips, transferred into a 15-ml conical tube, washed twice with PBS, and fixed with $4 \%$ paraformaldehyde in PBS overnight at $4^{\circ} \mathrm{C}$. Then they were embedded in frozen section compound OCT (Leica biosystems, Richmond, USA) followed by freezing in liquid nitrogen. Specimens were frozen-sectioned with 5- $\mu \mathrm{m}$ size using Leica CM3050S cryostat and processed for immunohistochemistry. The sections were incubated 
Table 1. List of gene-specific primers for the qRT-PCR analysis

\begin{tabular}{|c|c|c|}
\hline Gene & Accession number & Size (bp) \\
\hline 18s rRNA & $\begin{array}{l}\text { 5'-GCA ATT ATT CCC CAT GAA CG-3' } \\
\text { 5'-GGG ACT TAA TCA ACG CAA GC-3' }\end{array}$ & \\
\hline Integrin $\alpha 1$ & $\begin{array}{l}\text { 5'-GCA CCC ATT TTC CTT CTT CAT-3' } \\
\text { 5'-TGC TGC TGG CTC CTC ACT-3' NM_181501 }\end{array}$ & 145 \\
\hline Integrin $\alpha 2$ & $\begin{array}{l}\text { 5'-CAG TAA CCA GTT GCC TTT TGG-3' } \\
\text { 5'-GCT GGT GTT AGC GCT CAG TCA-3' }\end{array}$ & \\
\hline Integrin $\alpha 3$ & $\begin{array}{l}\text { 5'-GGT ACA CAG CAC CAG TCC -3' } \\
\text { 5'-GCC TCT TCG GCT ACT CGG TC-3' }\end{array}$ & \\
\hline Integrin $\alpha 4$ & $\begin{array}{l}\text { 5'-CCT GGC TGT CTG GAA AGT GT-3' } \\
5^{\prime} \text {-TAC AGA TGC AGG ATC GGA AAG -3' }\end{array}$ & 143 \\
\hline Integrin $\alpha 5$ & $\begin{array}{l}\text { 5'-TCC TGG CTG GCT GGT ATT AGC-3' } \\
\text { 5'-GCT TCA ACT TAG ACG CGG AGG-3' }\end{array}$ & 146 \\
\hline Integrin $\alpha 6$ & $\begin{array}{l}\text { 5'-CGT TCT GTT GGC TCT CTG CA-3' } \\
\text { 5'-ATC CGG AAA TAT GGA GAC CC-3' }\end{array}$ & \\
\hline Integrin $\alpha 7$ & $\begin{array}{l}\text { 5'-CAG TCT CCT CCA GGC TCA AC-3’ } \\
\text { 5'-CTT CTC TGT GGC CCT GCA C-3' NM_001144996 }\end{array}$ & 146 \\
\hline Integrin $\alpha 8$ & $\begin{array}{l}\text { 5'-CAC AGG CCA CAA CTT TTC CT-3' } \\
\text { 5'-CAG GCA GAT ACC GTT TGA CA-3' }\end{array}$ & \\
\hline Integrin $\alpha 9$ & $\begin{array}{l}\text { 5'CC"I C"IC CAG 'ICA CAII GC"I CA-3' } \\
\text { 5'-AGC TGC AGC TGA CTT ACA TGG-3' }\end{array}$ & 132 \\
\hline Integrin $\alpha 10$ & $\begin{array}{l}\text { 5'-AAT AGG CGT GGG TGA TGT TC-3' } \\
\text { 5'-GAC AGA AAC CGA TCA GGC AT-3' }\end{array}$ & 146 \\
\hline Integrin $\alpha 11$ & $\begin{array}{l}\text { 5'-GAC CCT TCC CAG GTT GAG TT-3' } \\
5^{\prime} \text {-GCA CGA CAT CAG TGG CAA TA-3' }\end{array}$ & 133 \\
\hline Integrin $\alpha \mathrm{E}$ & 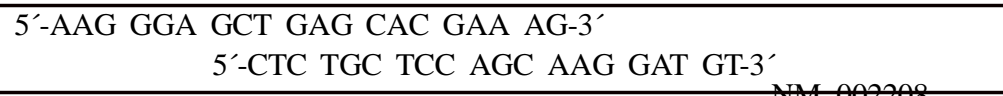 & \\
\hline Integrin $\alpha \mathrm{L}$ & 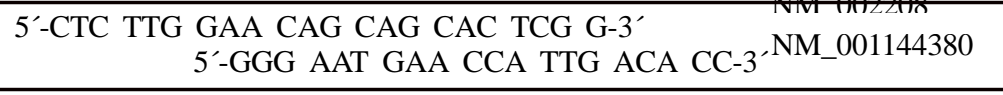 & 144 \\
\hline Integrin $\alpha \mathrm{M}$ & $\begin{array}{l}\text { 5'-AGA GAG CTT GGA GCC TGC TA-3' } \\
\text { 5'-ACG TAA ATG GGG ACA AGC T-3' }\end{array}$ & 146 \\
\hline Integrin $\alpha \mathrm{V}$ & $\begin{array}{l}\text { 5'-TGT TTC GAC CTC ACA GAT GCT-3' } \\
\text { 5'-TGT GAC TGG TCT TCT ACC CG-3' }\end{array}$ & 131 \\
\hline Integrin $\alpha 2 B$ & $\begin{array}{l}\text { 5'-CTC CAG GGG CAC AGG AAC AC-3' } \\
\text { 5'-CTT CCA CAA GGA CAG CCA T-3' }\end{array}$ & 149 \\
\hline Integrin $\alpha \mathrm{X}$ & $\begin{array}{l}\text { 5'-CAG TGC CTG CCC AAA ATA CT-3' } \\
\text { 5'-CAG GAG AGG AGG AGA ACC G-3' }\end{array}$ & 134 \\
\hline Integrin $\beta 1$ & $\begin{array}{l}\text { 5'-TTT CCT GCA GTA AGC ATC CAT-3' } \\
\text { 5'-CAT CCC TGA AAG TCC CAA GTG T-3' }\end{array}$ & \\
\hline Integrin $\beta 2$ & $\begin{array}{l}\text { 5'-ACT CCT GAG AGA GGA CGC ACC-3' } \\
\text { 5'-CCA GGG CAG ACT GGT AGC AA-3' }\end{array}$ & \\
\hline Integrin $\beta 3$ & $\begin{array}{l}\text { 5'-TCA TCA GAG CAC CAG GCA-3' } \\
5^{\prime} \text {-TCT GGG CGA CTG TGC TG-3' }\end{array}$ & 136 \\
\hline Integrin $\beta 4$ & $\begin{array}{l}\text { 5'-GGG AGT CAA CTT CTT GCA GC-3' } \\
\text { 5'-AAG TCC CAG GTC TCC TAC CG-3' }\end{array}$ & $44 \pi$ \\
\hline Integrin $\beta 5$ & $\begin{array}{ll}\text { 5'-AGC AGT TAC AGT TGT CCC CG-3' } & \text { NM_002213 } \\
\text { 5'-GGC AAG ATC TAT GGG CCT TT-3' } & \end{array}$ & 142 \\
\hline Integrin $\beta 6$ & $\begin{array}{l}\text { 5'CAC CTC AGA CCG CAG TTC TT-3' } \\
\text { 5'-TTG ATC TTC GCT GTA ACC CAA-3' }\end{array}$ & 150 \\
\hline
\end{tabular}


Table 1. Continued

\begin{tabular}{|c|c|c|}
\hline Gene & Accession number & Size (bp) \\
\hline Integrin $\beta 7$ & $\begin{array}{l}\text { 5'-GAC GCG GTG AAG TTC AGT TG-3' } \\
\text { 5'-ACA GGG GAT GCC ACA GAA T-3' }\end{array}$ & \\
\hline Integrin $\beta 8$ & $\begin{array}{l}\text { 5'-CAC AGG ATG CTG CAT TTG AA-3' } \\
\text { 5'-TTT ACC GCT GCA TTT GTC TG-3' }\end{array}$ & \\
\hline E-cadherin & $\begin{array}{l}\text { 5'-GTC GAG GGA AAA ATA GGC TG-3' } \\
\text { 5'-GCC GAG AGC TAC ACG TTC AC-3' }\end{array}$ & \\
\hline N-cadherin & $\begin{array}{l}\text { 5'-CCA CCT TAA AAT CTG CAG GC-3' } \\
\text { 5'-GTG CAT GAA GGA CAG CCT CT-3' }\end{array}$ & \\
\hline M-cadherin & $\begin{array}{l}\text { 5'-CAG GGG TAC AGG GTG GTG G-3' } \\
\text { 5'-GCG TTC CTC CTC GTC CTC-3' }\end{array}$ & 92 \\
\hline P-cadherin & $\begin{array}{l}\text { 5'-CAG TGC TAA ACA GAG CTG GC-3' } \\
5^{\prime} \text {-AGG CTG AAG TGA CCT TGG AG-3' }\end{array}$ & 108 \\
\hline VE-cadherin & $\begin{array}{l}\text { 5'-CAT CTT CCC AGG AGG AAC AGA-3' } \\
\text { 5'-AGA GCT CCA CTC ACG CTC AG-3' }\end{array}$ & \\
\hline ALCAM & $\begin{array}{l}\text { 5'-CTT CTG CCT CTT GAT CTC CG-3' } \\
\text { 5'-GAG GTA CGT CAA GTC GGC AAG-3' }\end{array}$ & \\
\hline CEACAM1 & $\begin{array}{l}\text { 5'-GAG AGG CCA TTT TCT TGT GG-3' } \\
\text { 5'-GGG ACG TAT TGG TGT TAG GT-3' }\end{array}$ & \\
\hline ЕрСАМ & 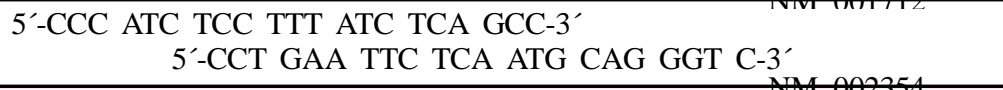 & \\
\hline ICAM & 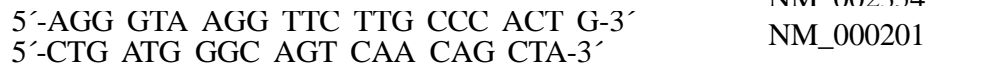 & 109 \\
\hline NCAM & 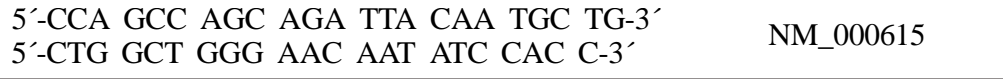 & 101 \\
\hline VCAM & $\begin{array}{l}\text { 5'-TGG GAA AAA CAG AAA AGA GGT GG-3' } \\
\text { 5'-GTC TCC AAT CTG AGC AGC AAT-3' }\end{array}$ & \\
\hline MMP1 & 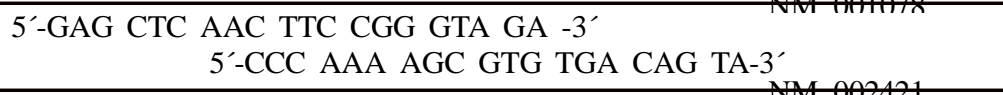 & \\
\hline MMP2 & $\begin{array}{l}\text { 5'-GTG TAG GTG TAA ATG GGT GCC ATC-3' } \\
\text { 5'-AAC TAC GAT GAC GAC CGC AAG TG-3' }\end{array}$ & 146 \\
\hline MMP9 & $\begin{array}{l}\text { 5'-GCA CTG CAG GAT GTC ATA GG-3' } \\
5^{\prime} \text {-ACG ACG TCT TCC AGT ACC GA-3' }\end{array}$ & 128 \\
\hline MMP14 & $\begin{array}{l}\text { 5'-AAG GCC AAT GTT CGA AGG AAG-3' } \\
\text { 5'-GGC CTC GTA TGT GGC ATA CTC-3' }\end{array}$ & 120 \\
\hline MMP15 & $\begin{array}{l}\text { 5'-GCG CTT CAA CGA GGA GAC A-3' } \\
5^{\prime} \text {-TCC AGT ATT TGG TGC CCT TGT-3' }\end{array}$ & 146 \\
\hline MMP16 & $\begin{array}{l}\text { 5'-ATG ATT TAC AGG GCA TCC AGA A-3' } \\
\text { 5'-TGG AGG CCG AGG AGG TTT-3, NM_005941 }\end{array}$ & 146 \\
\hline MMP17 & $\begin{array}{l}\text { 5'-GCG GGT ATC CTT CCT CTA CGT-3' } \\
\text { 5'-CAG CGA CCA CAA GAT CGT CTT-3' }\end{array}$ & \\
\hline TIMP1 & $\begin{array}{l}\text { 5'-ACT TGG CCC TGA TGA CGA G-3' } \\
5^{\prime}-\text { CTG TTG TTG CTG TGG CTG AT-3' }\end{array}$ & 103 \\
\hline TIMP2 & $\begin{array}{l}\text { 5'-TCC TCT TGA TAG GGT TGC CA-3' }^{\prime} \text { 5'- CGT TTT GCA ATG CAG ATG TA-3' }\end{array}$ & 9 \\
\hline TIMP3 & $\begin{array}{l}\text { 5'-ATG GTG TAG ACC AGC GTG C-3' } \\
5^{\prime} \text {-CAG GAC GCC TTC TGC AAC TC-3' }\end{array}$ & 98 \\
\hline TIMP4 & $\begin{array}{l}\text { 5'-GGC TCG ATG TAG TTG CAC AG-3' } \\
5^{\prime} \text {-ACG CCT TTT GAC TCT TCC CT-3' }\end{array}$ & 125 \\
\hline
\end{tabular}


with mouse monoclonal antibodies against integrin $\alpha 2$ (1:50; Santa Cruz, CA), rabbit monoclonal antibodies against integrin a2B (1:100; Abcam, Cambridge, MA) and mouse monoclonal antibodies against integrin $\alpha \mathrm{X}$ (1:50; Santa Cruz) overnight at $4^{\circ} \mathrm{C}$. They were then incubated with secondary antibodies: goat anti-rabbit IgGFITC (1:200, Santa Cruz), goat anti-rabbit IgG-TRITC (1:200, Santa Cruz). Cell nuclei were stained with 4'-6' diamidino-2-phenylindole (DAPI). They were visualized by confocal microscope (C1+, Nikon).

\section{Western blot analysis}

The protein samples were separated on 10\% SDS polyacrylamide gel electrophoresis (SDS-PAGE) gels and then transferred to nitrocellulose membranes (Millipore, Bedford, MA). The membranes were incubated with the mouse monoclonal antibodies against integrin $\alpha 2$ (1:100; Santa Cruz), integrin $\alpha \mathrm{X}$ (1:100; Santa Cruz) and $\beta$ actin (1:2,000; Santa Cruz) in blocking buffer (5\% BSA in DPBS) overnight at $4^{\circ} \mathrm{C}$. They were incubated in HRP-conjugated secondary goat anti-mouse IgG for $1 \mathrm{~h}$ at $37^{\circ} \mathrm{C}$. The stained membranes were visualized by ECL kit (ATTO, Tokyo, Japan). Blotting experiments were repeated three times on every sample with similar results.

\section{Blocking antibody assay}

HEACs at p3-p6 were seeded on 12-well dish at a density of $7.3 \times 10^{4}$ cells/well. After 7 days of culture of HEACs, cells were treated with each $10 \mu \mathrm{g} / \mathrm{ml}$ of antibody against integrin $\alpha 2$, $\alpha 2 \mathrm{~B}$ or $\alpha \mathrm{X}$ for $1 \mathrm{~h}$ at $37^{\circ} \mathrm{C}$. Each antibody was added to DMEM containing 0.5\% BSA and treated for $1 \mathrm{~h}$. After that, cells of each well was washed with DMEM and cultivated in medium containing $10 \%$ HS. They were cultivated for 20 days.

\section{Gelatin zymography}

Gelatinase activity of the conditioned medium was examined by gelatin zymography, which was performed as described previously (Park et al., 2005). Briefly, $10 \mu \mathrm{l}$ of conditioned medium was mixed with the same volume of non-reducing sample buffer consisting of $500 \mathrm{mM}$ Tris- $\mathrm{HCl}, 25 \%$ glycerol, 10\% SDS, and 0.32\% bromophenol blue (pH 6.8). Gelatin substrate for SDS-PAGE was prepared by adding $1 \mathrm{mg} / \mathrm{ml}$ bovine skin type B gelatin to the $8 \%$ resolving gel. After electrophoresis, gelatin-SDS gels were soaked with 2.5\% Triton X 100 in $50 \mathrm{mM}$ Tris-HCL buffer $(\mathrm{pH}$ 8.0) for $30 \mathrm{~min}$ and then incubated with incubation buffer ( $5 \mathrm{mM} \mathrm{CaCl}_{2}, 0.02 \% \mathrm{NaN}_{3}, 50 \mathrm{mM}$ Tris-HCl, $\mathrm{pH}$ 8.0) overnight at $37^{\circ} \mathrm{C}$. At the end of the incubation, the gels were stained with Coomassie Brilliant Blue. All zymographic results were confirmed experiments three times.

\section{Statistical analysis}

Data were presented as a mean \pm SEM. Statistical significance was analyzed by one-way ANOVA test and $t$-test using IBM SPSS Statistics 20. $P$-value $<0.05$ was considered to be statistically significant.

\section{RESULTS}

\section{Aggregation of HEACs by HS}

After around 6 days of culture of HEACs in a medium containing HS (HS medium), one or more cell-free area appeared in the surface of wells, and after 11 days, a population of cells nearby cell-free area became aggregated forming one or several cell clumps each well (Fig. 1). In many cases, morphology of the aggregates spheroid or ovoid but some were amorphous. In contrast, when cells were cultivated in FBS medium, HEACs did not show any morphological change until the end of culture. Interestingly, the formation of cell aggregation took place several times in a single spot, and proceeded very quickly such that cell migration and/or aggregation was hardly observed. The HS-induced aggregation was mostly observed between 9 and 15 days of culture.

\section{Expression of cell adhesion molecules in HS-agg} and HS-ex

It was investigated whether the formation of aggregation 


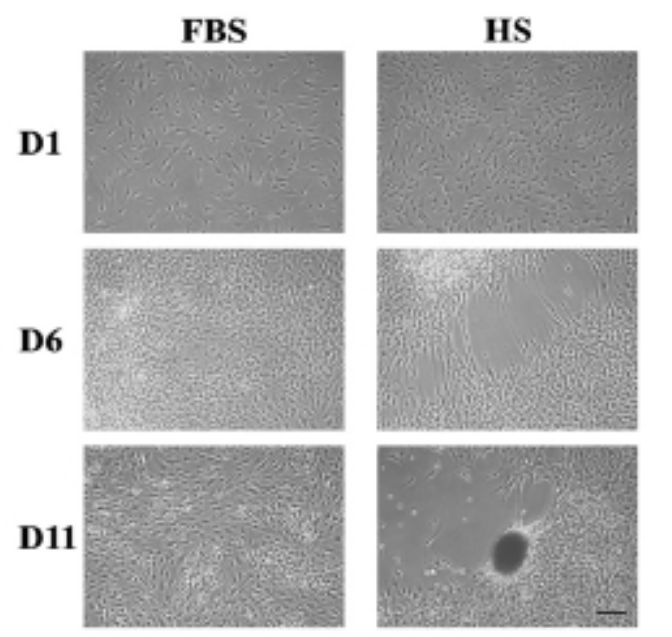

Fig. 1. Morphological change of HEACs during high-density culture in HS medium. Morphology of HEACs cultivated with $10 \%$ FBS or $10 \%$ HS for 1,6 and 11 days. Scale bar=0.2 $\mathrm{mm}$.

was accompanied by the change of cell adhesion molecules. When cell aggregation was formed, both HS-agg and HS-ex were examined for the expression of the related genes. qRT-PCR analyses showed that among 17 members of integrin $\alpha$ family examined, expression of $\alpha 2, \alpha 2 B$, and $\alpha \mathrm{X}$ in HS-agg were greater by a factor of $5.2 \pm 1.8$, $6.8 \pm 0.8$, and $4.9 \pm 1.8$, respectively, compared to the values of FBS-cultured cells. mRNA expression of the same genes in HS-ex did not show any significant change compared to the controls (Fig. 2A). Among the 8 members of integrin $\beta$ family examined, $\beta 2$ and $\beta 8$ expression in HS-agg were slightly greater than those of control cells, but it was not significant. Interestingly $\beta 5$ mRNA expression in HS-agg decreased. Again HS-ex did not show significant difference from that of the control (Fig. 2B). We have also examined mRNA expression of 11 cell adhesion molecules, and CEACAM1 mRNA of HS-agg showed 3.6 4 1.4-fold increased expression level compared to the FBS control while other mRNAs were not significantly different from the control (Fig. 2C). Immunocytochemical analyses demonstrated that integrin proteins of $\alpha 2, \alpha 2 \mathrm{~B}$ and $\alpha \mathrm{X}$ were distinctly expressed in HS-agg of HEACs, while they were not detected in HS-ex or control FBS-cultured cells (Fig. 3).

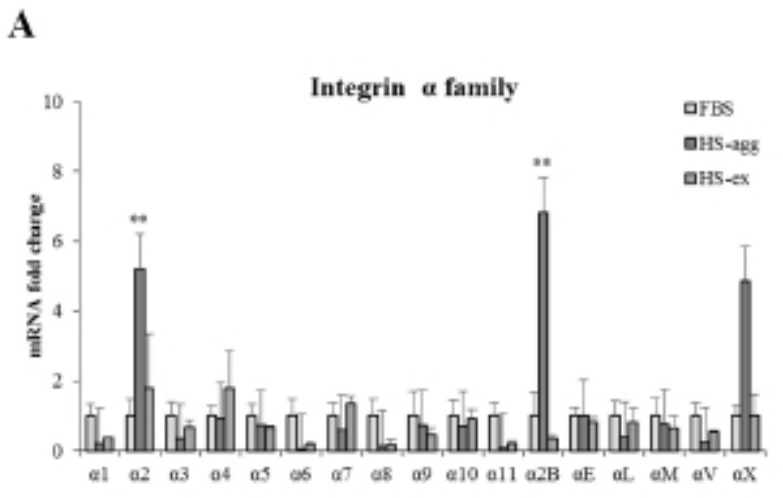

B

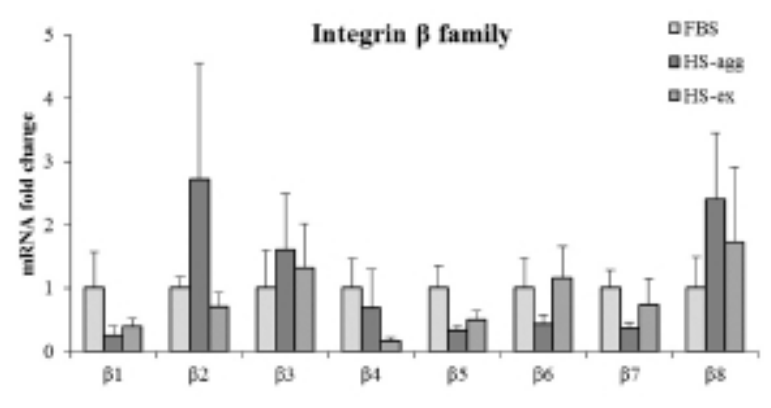

$$
\text { C }
$$

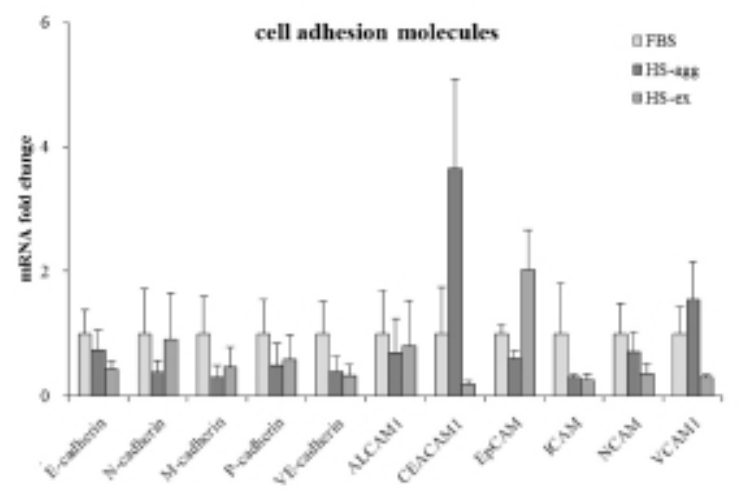

Fig. 2. Quantitative RT-PCR analyses of mRNA expression of the integrins, CAMs and cadherins by HEACs after culture in FBS or HS medium. Expression of integrin $\alpha$ family genes (A), integrin $\beta$ family genes (B), and genes of cell adhesion molecules (C) were examined after HEACs culture in FBS or HS. Aggregated cells (HS-agg) and non-aggregated ones (HS-ex) were separately examined. ${ }^{* *} P<0.01,{ }^{*} P<0.05$.

3. Effect of anti-integrin antibody on the aggregation

Results of western blot analysis showed that staining intensity of $\alpha 2$ and $\alpha \mathrm{X}$ proteins in HS-agg was stronger than that in HS-ex and FBS-cultured cells (Fig. 4A). 
H Yang, YH Lim, S Yun, AY Yoon, H Kim

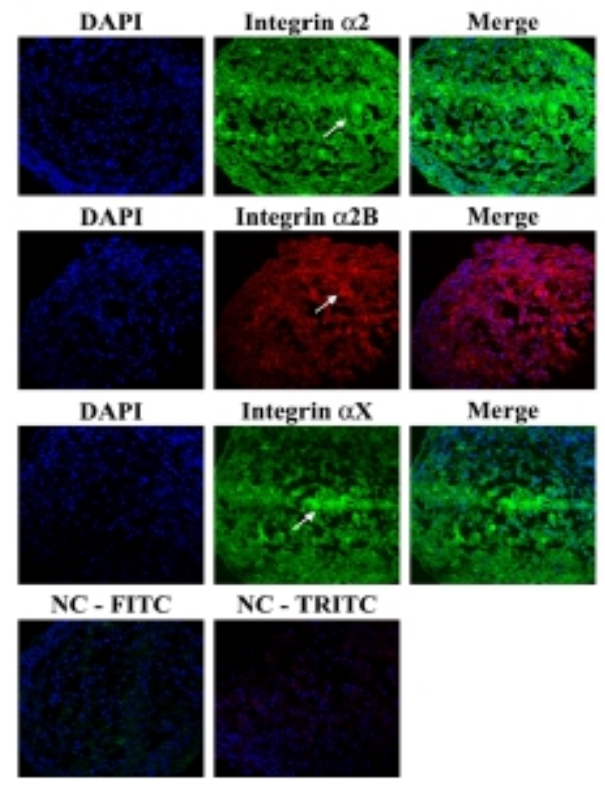

Fig. 3. Immunocytochemistry of HS-agg HEACs after culture in HS medium for the integrin $\alpha 2, \alpha 2 B$ and $\alpha \mathrm{X}$ proteins. Immunofluorescence was detected against the integrin $\alpha 2$, integrin $\alpha 2 \mathrm{~B}$ and integrin $\alpha \mathrm{X}$ proteins in aggregation of HEACs. Arrows indicate the intense staining area. $\times 400$. NC, negative control.

A

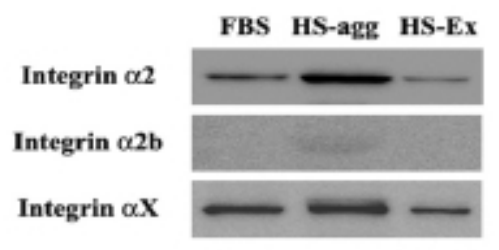

B

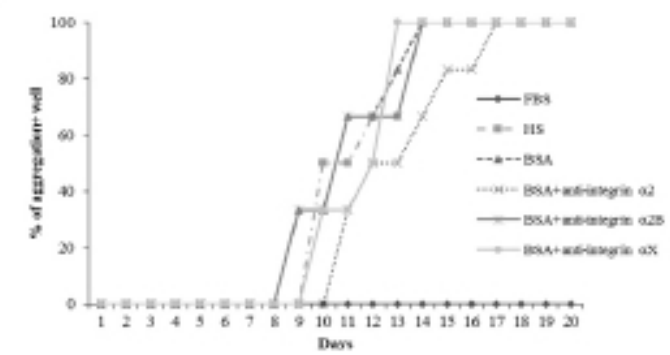

Fig. 4. Expression of integrin $\alpha 2$ and integrin $\alpha \mathrm{X}$ proteins in HEACs and effects of their antibodies on the HS-induced aggregation. (A) Western blot analysis of integrin $\alpha 2$ and integrin $\alpha \mathrm{X}$ proteins in HEACs after culture in FBS or HS. Note the stronger intensity of integrin $\alpha 2$ $(150 \mathrm{kDa})$ and integrin $\alpha \mathrm{X}(145 \mathrm{kDa})$ protein bands in HS-agg cells compared to the HS-Ex or cells cultivated in FBS. (B) Effects of anti-integrin antibodies on the aggregation of HEACs. Integrin $\alpha 2$-blocking antibody delayed aggregation by about 2 days, while integrin a 2B- and integrin $\alpha \mathrm{X}$-blocking antibodies showed little effect on the formation of aggregation.
After 7 days of culture in HS medium, cells were treated with each $10 \mu \mathrm{g} / \mathrm{ml}$ of antibodies against integrin $\alpha 2$, $\alpha 2 \mathrm{~B}$ or $\alpha \mathrm{X}$ for $1 \mathrm{~h}$, and then cultivated again in HS medium. Of the antibodies examined, integrin $\alpha 2$ antibody showed delayed aggregation by 4 days compared to the control HS-culture. Antibodies against $\alpha 2 \mathrm{~B}$ and $\alpha \mathrm{X}$ did not show any delaying effect on the HS-induced aggregation (Fig. 4B).

\section{Role of MMPs and TIMPs in HS-induced aggregation} of the HEACs

To examine if MMPs were involved in the aggregation, expression of various MMPs and membrane-type MMPs (MT-MMPs) were examined in HS-agg and HS-ex as well as in FBS-cultured cells by qRT-PCR (Fig. 5A). Among the 7 MMPs, MMP1 and MMP9 were strongly expressed in HS-agg. In case of MMP1, HS-agg showed

A

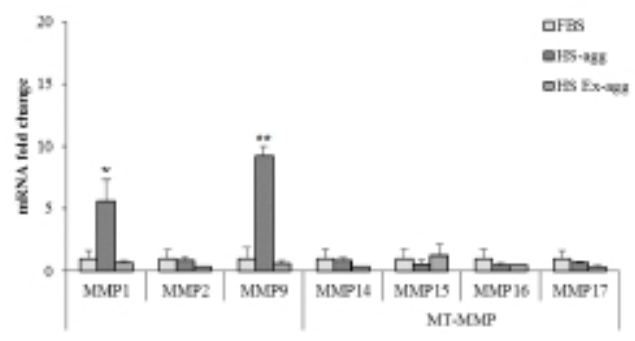

B

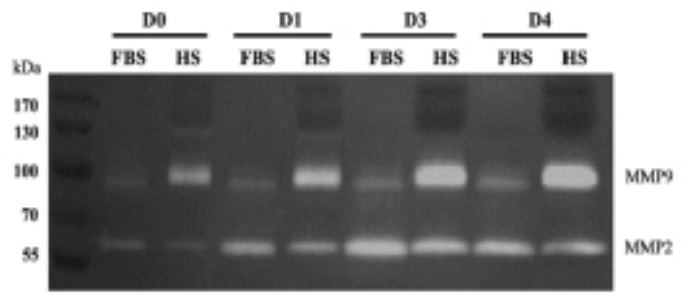

Fig. 5. Expression of the MMPs by HEACs after culture in FBS or HS medium. (A) Quantitative RT-PCR analyses of mRNA expression of the MMPs in HEACs after culture in FBS or HS medium. Expression of MMP's genes by aggregated HEACs and ex-aggregated HEACs were compared to those expressed by FBS-cultured HEACs. ${ }^{* *} P<0.01$, $* P<0.05$. (B) Gelatin zymography of the HEACs-conditioned media. HEACs were cultivated for 4 days in FBS- or HS-containing medium. During culture, cell-conditioned media were collected every day and examined for the gelatinolytic activity of MMP2 (62 kDa) and MMP9 (92 $\mathrm{kDa}$ ). Note that MMP9 activity remarkably increased as the culture continued in HS medium. 


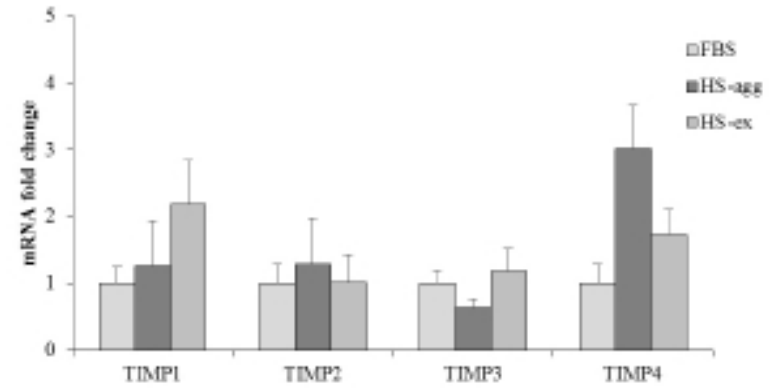

Fig. 6. Quantitative RT-PCR analyses of mRNA expression of the TIMPs. Expression of TIMP genes by aggregated HEACs, ex-aggregated HEACs on the basis of FBS cultured HEACs.

5.6 \pm 1.8 -fold increased expression compared to the FBScultured cells. Moreover, HS-agg exhibited 9.2 \pm 0.8 -fold increased MMP9 expression compared to the FBS-cultured cells. HS-ex did not show any increased expression than FBS-cultured cells. Other MMPs did not show significant changes of mRNA expression regardless of the HS treatment.

It was further examined by using gelatin zymography whether there was any changes of MMP activity in relation to the cell aggregation phenomenon. Conditioned media were obtained every day from cell cultures in FBS or HS medium during culture for 4 days. Strikingly HS-conditioned media exhibited a dramatic increase of MMP9 gelatinolytic activity beginning from 1 day culture (Fig. 5B). In contrast, conditioned media from cell cultures in FBS medium showed little MMP9 activity throughout 4 days. MMP2 activity of both FBS- and HS-conditioned media was discernable after culture for 1 day. While MMP2 activity of FBS-conditioned media showed a little increase thereafter, that of HS-conditioned media remained unchanged during 4 days. Both HS-agg and HS-ex showed a similar expression level of all four genes of TIMP-1, -2, -3 and -4 as compared to the FBS-cultured cells (Fig. 6). Although TIMP-4 mRNA expression appeared to be greater in HS-agg than other groups, it was not significantly different.

\section{DISCUSSION}

The highlight of this study is a finding that integrins $\alpha 2, \alpha 2 \mathrm{~B}, \alpha \mathrm{X}, \mathrm{CEACAM} 1$, and MMP9 of HEACs undergo remarkable changes of expression when cells are aggregated by HS-culture. In mammals, eighteen $\alpha$ subunits and eight $\beta$ subunits of integrins have been identified to date, from which 24 distinct heterodimer combinations have been observed (Prowse et al., 2011). Integrin ligation via cell-to-cell and cell-to-matrix contacts activates signaling pathways involved with differentiation, proliferation, and gene expression. Integrin $\alpha 2$ is combined with integrin $\beta 1$ and functions as a signal transmitter for platelet activation (Jarvis et al., 2012). In addition to the increased expression of ITGA2 mRNA, treatment of its antibody showed delayed formation of aggregation in the present study, supporting the its role in migration during aggregation. Integrin $\alpha 2 \mathrm{~B}$ is also expressed in platelet, which forms heterodimer with integrin $\beta 3$ (Neumann et al., 1998). A previous study has shown that the inhibition of the integrin $\alpha 2 \mathrm{~B} \beta 3$ receptor significantly impairs platelet recruitment to the growing thrombus. This observation suggests that platelet recruitment to venous stent thrombi occurs through the integrin $\alpha 2 \mathrm{~B} \beta 3$ receptor, at least in part (McBane et al., 2013). However, western blot results demonstrate that $\alpha 2 \mathrm{~B}$ protein expression was hardly observed in the present study. Integrin $\alpha \mathrm{X}$ is combined with integrin $\beta 1$ and interacts with iC3b and fibrinogen. It is expressed in leukocyte, which is involved with leukocyte emigration from the blood (Kaneider et al., 2010). Together with these results, our study suggests that integrins $\alpha 2$ and $\alpha \mathrm{X}$ induced by HS culture might be involved in HS-induced aggregation during high-density culture. CEACAM1 was identified as possible mediators in HGF-induced keratinocyte migration and the functional relevance of CEACAM1 on epidermal cell motility was demonstrated using the HaCaT cell culture model (Schnickmann et al., 2009). In an implantation model of trophoblast spheroids on a monolayer of endometrial stromal cells, spheroid expansion was blunted by silencing of CEACAM1 (Gellersen et al., 2013). Inhibition of CEACAM1 with antibodies or soluble CEACAM1 or antisense oligonucleotides inhibited tubule formation of prostate cells 
grown in Matrigel by over 50\% (Zhang et al., 2013). Results of these and our study together suggest an important role of CEACAM1 in cell migration.

Among seven members of MMP family examined, we found that mRNA expression of MMP1 and MMP9 genes specifically increased in HS-agg compared to the HS-Ex as well as control FBS-cultured cells. Also we observed an increased activity of MMP9 in conditioned medium obtained from HS-culture compared to the FBS-culture during successive 4 day-culture. In keratinocytes, cell migration is regulated by the catalytic activity of MMP1, and by anti-a2 $\beta 1$ blocking antibodies (Dumin et al., 2001). Using liver-injured mouse models, MMP-9 has been shown to contribute to the mobilization of BM cells in the injured liver by up-regulating the expression of CXCR4 on Lin(-) BM cells and attracting BM cells along its gradient of CXCL12 (Kawai et al., 2012). In a recent study wherein abdominal adipose-derived stem cells following short-term spheroid formation were used, enhanced in vitro migration was observed to associate with increased expression of MMP9 and -13 (Cheng et al., 2013). Upon transplantation in murine model with cutaneous wounds, these cells exhibited more cellular engraftment. While a number of studies have suggested a combinatorial role of MMPs and integrins during cell migration in vivo and in vitro, little report has demonstrated a relationship between MMP-9 and integrin $\alpha 2$, $\alpha 2 \mathrm{~B}$ and $\alpha \mathrm{X}$ collagen receptor proteins. The present report, for the first time, suggest a possible role of MMP1 and MMP9 in migration and/or aggregation of human adult stem cells in vitro, via changes of integrins, the collagen receptor proteins.

HS has widely been studied by many researchers as a substitute of FBS in MSCs culture As well as pooled human $\mathrm{AB}$ serum, thrombin-activated platelet-rich plasma showed to provide a significantly higher proliferative effect on abdominal adipose tissue-derived MSCs (Kocaoemer et al., 2007; Bieback et al., 2010). These human supplements are better characterized regarding potential infectious threats, while providing a higher proliferation rate and retaining differentiation capacity and mesenchymal stem cell marker expression throughout long-term culture (Bieback et al., 2009). However, a higher proliferation effect of HS could not be a reason of cell aggregation as highdensity alone cannot induce the aggregation as shown in our previous study (Song et al., 2012). Rather it seems due to a yet-unknown property of HS which is not present in FBS. It would be interesting to study whether the cell aggregation could be induced by other animal sera.

In summary, our results showed that the expression of integrin $\alpha 2, \alpha 2 \mathrm{~B}$ and $\alpha \mathrm{X}$ in HS-agg increased during high-density culture in the presence of HS, and antibody against integrin $\alpha 2$ molecule delayed the aggregation. In addition, both MMP1 and MMP9 mRNA and MMP9 enzymatic activity also increased in HS-agg. Based on these results, it is suggested that integrins and MMPs might be involved in the HS-induced aggregation of HEACs.

\section{ACKNOWLEDGEMENTS}

This work was supported by a research grant from Seoul Women’s University (2012).

\section{REFERENCES}

Bianco P, Robey PG, Simmons PJ (2008) Mesenchymal stem cells: revisiting history, concepts, and assays. Cell Stem Cell 2:313-319.

Bieback K, Ha VA, Hecker A, Grassl M, Kinzebach S, Solz H, Sticht C, Klüter H, Bugert P (2010) Altered gene expression in human adipose stem cells cultured with fetal bovine serum compared to human supplements. Tissue Eng Part A 16:3467-3484.

Bieback K, Hecker A, Kocaömer A, Lannert H, Schallmoser K, Strunk D, Klüter H (2009) Human alternatives to fetal bovine serum for the expansion of mesenchymal stromal cells from bone marrow. Stem Cells 27:23312341.

Bieback K, Hecker A, Schlechter T, Hofmann I, Brousos 
A Role of Cell Adhesion Molecules and Gelatinases in Human Serum-Induced Aggregation of Human Eyelid-Derived Stem Cells

N, Redmer T, Besser D, Klüter H, Müller AM, Becker M (2012) Replicative aging and differentiation potential of human adipose tissue-derived mesenchymal stromal cells expanded in pooled human or fetal bovine serum. Cytotherapy 14:570-583.

Brooke G, Tong H, Levesque JP, Atkinson K (2008) Molecular trafficking mechanisms of multipotent mesenchymal stem cells derived from human bone marrow and placenta. Stem Cells Dev 17:929-940.

Carrion B, Kong YP, Kaigler D, Putnam AJ (2013) Bone marrow-derived mesenchymal stem cells enhance angiogenesis via their a6 $\beta 1$ integrin receptor. Exp Cell Res 319:2964-2476.

Cheng NC, Chen SY, Li JR, Young TH (2013) Short-term spheroid formation enhances the regenerative capacity of adipose-derived stem cells by promoting stemness, angiogenesis, and chemotaxis. Stem Cells Transl Med 2:584-594.

De Becker A, Van Hummelen P, Bakkus M, Vande Broek I, De Wever J, De Waele M, Van Riet I (2007) Migration of culture-expanded human mesenchymal stem cells through bone marrow endothelium is regulated by matrix metalloproteinase- 2 and tissue inhibitor of metalloproteinase-3. Haematologica 92:440-449.

Dumin JA, Dickeson SK, Stricker TP, BhattacharyyaPakrasi M, Roby JD, Santoro SA, Parks WC (2001) Pro-collagenase-1 (matrix metalloproteinase-1) binds the alpha(2)beta(1) integrin upon release from keratinocytes migrating on type I collagen. J Biol Chem 276:29368-29374.

Frith JE, Mills RJ, Hudson JE, Cooper-White JJ (2012) Tailored integrin-extracellular matrix interactions to direct human mesenchymal stem cell differentiation. Stem Cells Dev 21:2442-2456.

Gellersen B, Wolf A, Kruse M, Schwenke M, Bamberger AM (2013) Human endometrial stromal cell-trophoblast interactions: mutual stimulation of chemotactic migration and promigratory roles of cell surface molecules CD82 and CEACAM1. Biol Reprod 88:80.

Granero-Moltó F, Weis JA, Miga MI, Landis B, Myers
TJ, O'Rear L, Longobardi L, Jansen ED, Mortlock DP, Spagnoli A (2009) Regenerative effects of transplanted mesenchymal stem cells in fracture healing. Stem Cells 27:1887-1898.

Jarvis GE, Bihan D, Hamaia S, Pugh N, Ghevaert CJ, Pearce AC, Hughes CE, Watson SP, Ware J, Rudd CE, Farndale RW (2012) A role for adhesion and degranulationpromoting adapter protein in collagen-induced platelet activation mediated via integrin $\alpha(2) \beta(1)$. J Thromb Haemost 10:268-277.

Kaneider NC, Mosheimer B, Günther A, Feistritzer C, Wiedermann CJ (2010) Enhancement of fibrinogentriggered pro-coagulant activation of monocytes in vitro by matrix metalloproteinase-9. Thromb J 8:1-7. Kang HM, Kim J, Park S, Kim J, Kim H, Kin KS, Kim EJ, Seo SI, Kang SG, Lee JE, Lim H (2009) Insulinsecreting cells from human eyelid-derived stem cells alleviate type I diabetes in immunocompetent mice. Stem Cells Dev 27:1999-2008.

Kawai K, Xue F, Takahara T, Kudo H, Yata Y, Zhang W, Sugiyama T (2012) Matrix metalloproteinase-9 contributes to the mobilization of bone marrow cells in the injured liver. Cell Transplant 21:453-464.

Kocaoemer A, Kern S, Klüter H, Bieback K (2007) Human $\mathrm{AB}$ serum and thrombin-activated platelet-rich plasma are suitable alternatives to fetal calf serum for the expansion of mesenchymal stem cells from adipose tissue. Stem Cells 25:1270-1278.

McBane RD 2nd, Karnicki K, Wysokinski WE (2013) Platelet recruitment to venous stent thrombi. J Thromb Thrombolysis 36:442-427.

Mizuno H, Tobita M, Uysal AC (2012) Concise review: Adipose-derived stem cells as a novel tool for future regenerative medicine. Stem Cells 30:804-810.

Neumann FJ, Blasini R, Schmitt C, Alt E, Dirschinger J, Gawaz M, Kastrati A, Schömig A (1998) Effect of glycoprotein IIb/IIIa receptor blockade on recovery of coronary flow and left ventricular function after the placement of coronary-artery stents in acute myocardial infarction. Circulation 98:2695-2701. 
Prowse AB, Chong F, Gray PP, Munro TP (2011) Stem cell integrins: implications for ex-vivo culture and cellular therapies. Stem Cell Res 6:1-12.

Ries C, Egea V, Karow M, Kolb H, Jochum M, Neth P. (2007) MMP-2, MT1-MMP, and TIMP-2 are essential for the invasive capacity of human mesenchymal stem cells: differential regulation by inflammatory cytokines. Blood 109:4055-4063.

Sarkar D, Spencer JA, Phillips JA, Zhao W, Schafer S, Spelke DP, Mortensen LJ, Ruiz JP, Vemula PK, Sridharan R, Kumar S, Karnik R, Lin CP, Karp JM (2011) Engineered cell homing. Blood 118:184-191. Schnickmann S, Camacho-Trullio D, Bissinger M, Eils R, Angel P, Schirmacher P, Szabowski A, Breuhahn K (2009) AP-1-controlled hepatocyte growth factor activation promotes keratinocyte migration via CEACAM1 and urokinase plasminogen activator/urokinase plasminogen receptor. J Invest Dermatol 129:1140-1148.

Song Y, Yun S, Yang H, Yoon A, Kim H (2012) Aggregation of human eyelid adipose-derived stem cells by human body fluids. Dev Reprod 16:339-351.

Taniguchi Ishikawa E, Chang KH, Nayak R, Olsson HA, Ficker AM, Dunn SK, Madhu MN, Sengupta A, Whitsett JA, Grimes HL, Cancelas JA (2013) Klf5 controls bone marrow homing of stem cells and progenitors through Rab5-mediated $\beta 1 / \beta 2$-integrin trafficking. Nat Commun 4:1660

Tateishi K, Ando W, Higuchi C, Hart DA, Hashimoto J, Nakata K, Yoshikawa H, Nakamura N (2008) Comparison of human serum with fetal bovine serum for expansion and differentiation of human synovial MSC: potential feasibility for clinical applications. Cell Transplant 17:549-557.

Uccelli A, Moretta L, Pistoia V (2008) Mesenchymal stem cells in health and disease. Nat Rev Immunology 8:726-736.

Zhang H, Eisenried A, Zimmermann W, Shively JE (2013) Role of CEACAM1 and CEACAM20 in an in vitro model of prostate morphogenesis. PLoS One 8:e53359. 